\title{
Control of meiobenthic abundance by macroepifauna in a subtidal muddy habitat
}

\author{
Emil 'Olafsson*, Colin G. Moore \\ Department of Biological Sciences, Heriot-Watt University, Riccarton, Edinburgh EH14 4AS, Scotland
}

\begin{abstract}
In order to assess the effects of macrofauna on meiofaunal community structure, field investigations were performed in a low energy subtidal muddy sediment in Loch Creran, a sea-loch on the west coast of Scotland. Meiofaunal colonization of azoic sediment in cages designed to exclude macrofauna to varying degrees was studied. After 1 mo nematode density in all 15 cages was less than a third of ambient density. In none of the cages did the nematodes reach ambient densities within the experimental period. Copepods attained background levels in $3 \mathrm{mo}$ in all cages and were in higher numbers in cages designed to exclude all macrofauna. Results indicate that small to medium sized macroepifauna control the densities of copepods at the study site.
\end{abstract}

\section{INTRODUCTION}

Although meiofauna used to be regarded as a trophic dead end (McIntyre \& Murison 1973), it is now acknowledged as an important food resource for higher trophic levels. Meiofauna is preyed upon by the juveniles of a large number of fish species (see Gee 1989 for review) and other macrofaunal species including shrimps, crabs, polychaetes, and gastropods (Teal 1962, Bell \& Coull 1978, Nichols \& Robertson 1979, Bell 1980, Hockin 1982, Robertson \& Newell 1982, Hoffman et al. 1984, Gee et al. 1985, Pihl 1985, Gee 1987).

It has been a matter of controversy whether this predation regulates meiofaunal communities. Some predation studies indicate no significant impact on the abundance of the major meiofaunal groups (Alheit \& Scheibel 1982, Dauer et al. 1982, Hicks 1984, Sogard 1984, Gee et al. 1985, Gee 1987), while other experiments have shown decreases in meiofaunal abundance in the presence of predators/disturbers (Bell \& Coull 1978, Reise 1979, Scherer \& Reise 1981, Warwick et al. 1982, Fitzhugh \& Fleeger 1985, Smith \& Coull 1987. Palmer 1988a), or an increase when predators were excluded (Buzas 1978, Nichols \& Robertson 1979, Reise 1979, Bell 1980, Hoffman et al. 1984).

\footnotetext{
- Present address: Department of Zoology, University of Stockholm, S-106 91 Stockholm, Sweden

Apart from experiments conducted by Dauer et al. (1982) at a very shallow $(1.5 \mathrm{~m})$ sandy site, every predator exclusion experiment dealing with meiofauna has been performed intertidally and often on sandy substrata. In the intertidal zone abiotic factors such as salinity, temperature and current are unstable and regulate meiofaunal community structure to a great extent (see for example Jansson 1968, Harris 1972, Mielke 1976, Coull et al. 1979, Moore 1979). Subtidally these factors become more stable so biological factors might be expected to play a greater role in structuring the meiofaunal community. Predation on sediment meiofauna is believed to take place primarily in muddy or detrital substrata (Hicks \& Coull 1983, Smith \& Coull 1987 , but see Gee 1987) whereas in sand the greater depth of oxygenated sediment provides the opportunity to burrow and escape from predation (Coull \& Bell 1979).

Here we report on an exclusion experiment with the aim of assessing the extent to which meiofaunal communities are structured by macrofauna in subtidal muddy sediments. In order to reduce the risk of physical artefacts associated with small mesh size we have defined macrofauna as those animals that cannot enter $1 \mathrm{~mm}$ cages. In this paper we concentrate on changes in meiofaunal density due to exclusion of macrofauna. In subsequent contributions changes in other community parameters will be reported. 


\section{STUDY AREA}

Loch Creran is a sea-loch situated on the west coast of Scotland. The loch consists of 2 interconnected basins, a large lower basin $\left(11.49 \mathrm{~km}^{2}\right)$ and a small upper basin $\left(2.04 \mathrm{~km}^{2}\right)$ and is linked to the outside sea area via shallow rocky sills (Gage 1972a). At least 2 macrobenthos surveys have been performed in the loch (McIntyre 1956, Gage 1972a, b). Hydrographic measurements carried out by Gage (1972a) show that the salinities near the bottom are comparable to those outside in the Firth of Lorne, ranging from ca 31 to $33 \%$. The temperature regime is also similar to that found outside, ranging from 6 to $15^{\circ} \mathrm{C}$.

Following a pilot survey a site in the lower basin was chosen as a study area. This site is located about $100 \mathrm{~m}$ off Rubha Rieabhach Craigs ( $56^{\circ} 31^{\prime} 16^{\prime \prime} \mathrm{N}, 5^{\circ} 20^{\prime} 38^{\prime \prime} \mathrm{W}$ ) at $11 \mathrm{~m}$ depth where the seabed is level and consists of soft mud.

\section{MATERIALS AND METHODS}

Exclusion cages and several types of controls were established on the seabed. The basic cage design consisted of a plastic box framework, with a solid plastic bottom (Fig. 1). A lid frame was constructed of aluminium angle-iron and tied to the cage with thin wire. The lid and sides of the cage were either composed of nylon netting or left open, depending upon the treatment. Six treatments, each of 3 replicates, were employed. The codes and details of the treatments are as follows:

1 (1 mm cages): These cages were covered in $1 \mathrm{~mm}$ aperture mesh, being designed to exclude macrofauna. 1C (1 mm control cages): These were identical to the $1 \mathrm{~mm}$ cages, except that the 2 narrower ends of the cage framework were left open. This allowed entry of macrofauna, while producing similar current and sedimentary regimes within the cages. The meshed sides of the cage were placed normal to the prevailing current direction.

10 (10 mm cages): These cages were covered in $10 \mathrm{~mm}$ aperture mesh, being designed to exclude only the larger macrofauna.

$10 \mathrm{C}(10 \mathrm{~mm}$ control cages): Identical to the $10 \mathrm{~mm}$ cages apart from the 2 ends of the cages remaining unmeshed.

OC (Open control cages): These consisted of the basic cage framework, all sides and the top remaining unmeshed. These permitted examination of biotic changes resulting from unwanted modification of the physical and chemical conditions within the other cage types.

BC (Background controls): Areas of seabed, each of approximately the same surface area as an exclusion cage, were delimited with wooden pegs.

To establish the cages SCUBA divers first inserted a metal frame in the sediment and removed the contents down to $10 \mathrm{~cm}$ with an airlift (Fig. 1). Each cage, weighted with a brick, was sealed in a plastic bag and placed in the hole. Cages were placed in random order at $2 \mathrm{~m}$ intervals along 2 arrays $2 \mathrm{~m}$ apart. Approximately $200 \mathrm{l}$ of surface sediment was collected by divers from the vicinity of the study area and brought back to the laboratory. The mud was agitated and all larger animals picked out. Then plastic trays $(38 \times 31 \times 8 \mathrm{~cm})$ were used as moulds to make frozen sediment blocks. Prior to the experiment the effects of freezing on softness and texture of the mud, as well as the animal life, were studied. It was found that all animals died as a result of freezing and the mud returned to a smooth consistency after thawing. When all cages were in situ the mudblocks were inserted and the weighting bricks and plastic bags removed.

The experiment was initiated in June 1986 and meiofaunal samples and salinity and temperature measurements were taken monthly from July to September 1986 and in February 1987. Samples from the second month, in August, were not analyzed in order to cut
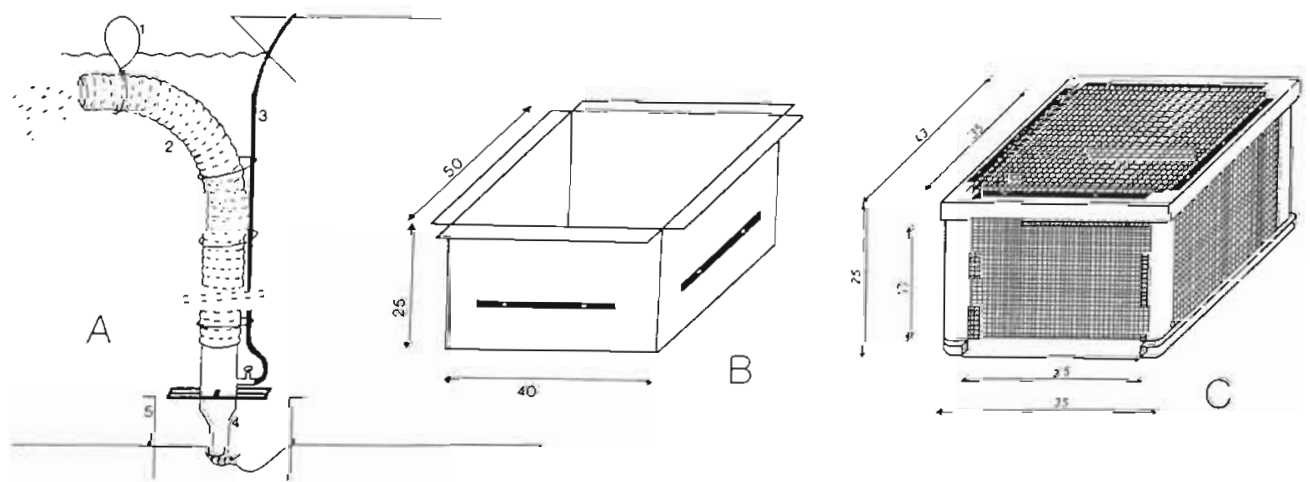

Fig. 1. Schematic diagram of an airlift (A) sucking out bottom contents from inside an aluminum digging frame (B) $(1=$ buoy, $2=$ flexible hose, 3 = air hose, 4 = sucking tube, 5 = digging frame in situ) and an exclusion cage (C). All measurements in centimetres 
down extensive processing time. From each replicate cage three $5 \mathrm{~cm}$ deep cores, each of $11.34 \mathrm{~cm}^{2}$ crosssectional area, were retrieved with hand-held perspex tubes and preserved in $4 \%$ seawater formalin. The meiofauna was extracted from the sediment by centrifugation in Ludox TM colloidal silica (Platt \& Warwick 1983) using a $45 \mu \mathrm{m}$ mesh sieve. It was found that on average ( $n=16$ ) the extraction efficiency for the nematodes, copepods and other groups was 95, 80 and $86 \%$ respectively. The meiofauna was enumerated and identified to major taxa in a petri dish under a stereo dissecting microscope.

Redox depth profiles inside and outside cages were measured using the method of Pearson \& Stanley (1979) with a standard redox electrode, after 3 and 8 mo. On each sampling date cages were cleaned in order to remove fouling animals and detrital matter.

In order to assess macrobenthic activity within the cages and control area, the bottom of each cage was photographed on each sampling occasion and one Ekman grab of area $0.02 \mathrm{~m}^{2}$ was taken from one replicate cage of each treatment and one background area in September 1986 and February 1987, the macrofauna being extracted on a $1 \mathrm{~mm}$ mesh sieve. The replicate cages and the background area sampled with the Ekman grab were not sampled again after 8 mo.

For each taxon differences in density between the treatments, and temporal differences in density within each treatment were investigated by means of nested analyses of variance. Even if no differences were found between core samples within treatments these samples were not regarded as replicates to allow more powerful 1 -way ANOVA as suggested by several authors (Underwood 1982, Berge \& Valderhaug 1983, Raffaelli \& Milne 1987 ) as this would introduce pseudoreplication (Hurlbert 1984). Before the analyses of variance, all data were first log-transformed and Bartlett's test used for checking homoscedasticity. When conditions for parametric tests were not fulfilled, Kruskal Wallis 1-way analyses by ranks and Mann-Whitney U tests were employed on pooled core counts from each replicate cage.

\section{RESULTS}

\section{Abiotic factors}

Bottom salinity ranged from 28 to $30 \%$ during the experiment. The maximum bottom temperature was recorded in September $\left(12.5^{\circ} \mathrm{C}\right)$ and the minimum in February $\left(7^{\circ} \mathrm{C}\right)$. These fluctuations are in accordance with measurements for the same area taken by Gage (1972a).

It was clear that the sediment inside all the cages had not developed abnormal reducing conditions (Fig. 2). The $1 \mathrm{~mm}$ cages which one would expect to be most

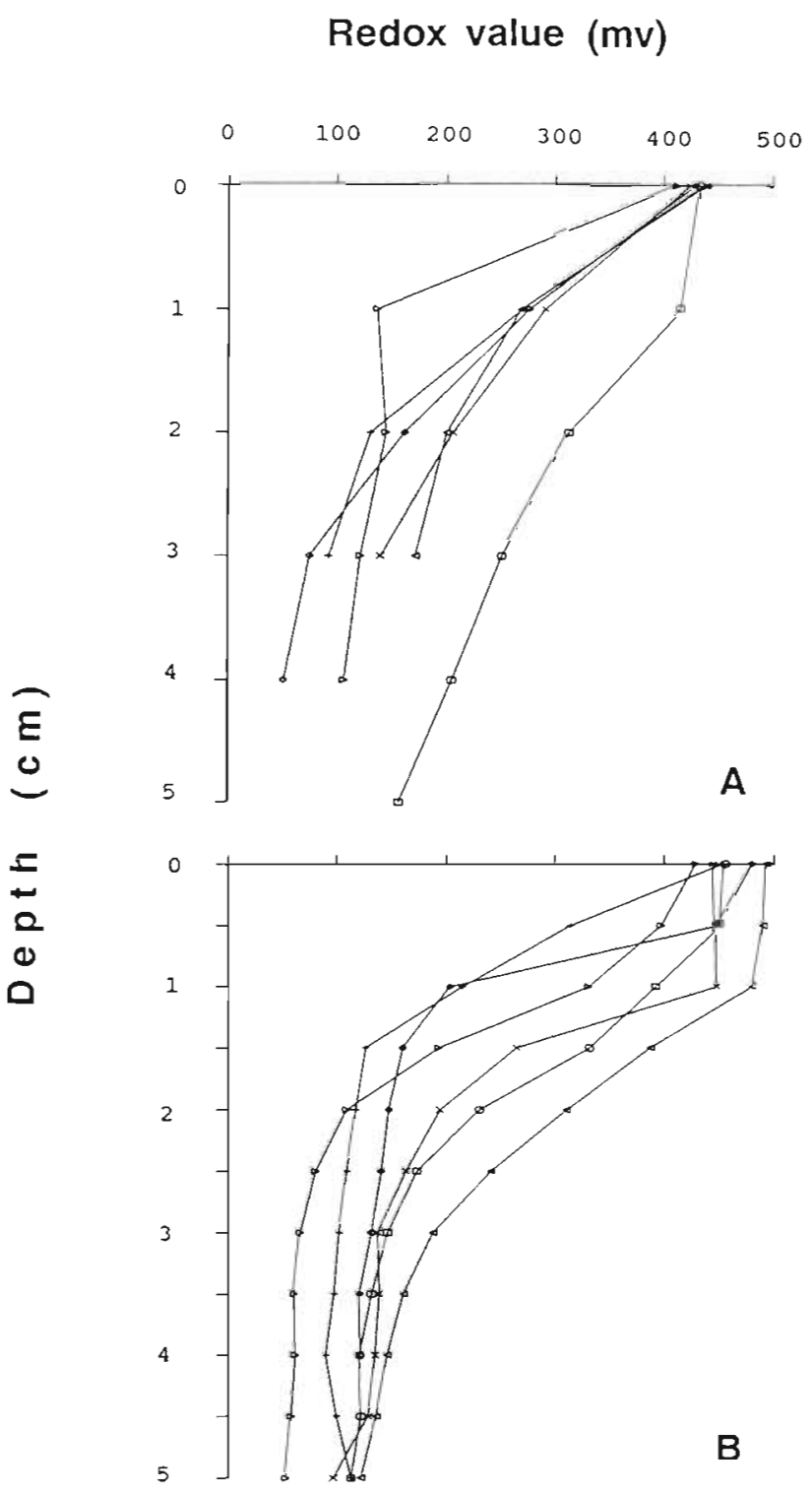

Fig. 2. Average $(\mathrm{n}=2$ ) redox measurements (mv) from one replicate cage of each treatment after (A) 3 mo and (B) 8 mo. Treatments presented are: (ㄷ) background control; ( + ) open control cages; ( $) 10 \mathrm{~mm}$ control cages; (D) $10 \mathrm{~mm}$ cages; $(x)$ $1 \mathrm{~mm}$ control cages; (๑) $1 \mathrm{~mm}$ cages

susceptible to the promotion of anaerobiosis were after 3 mo similar to the rest of the cages and showed the highest redox levels after 8 mo.

\section{Macrofauna}

After 3 mo both macrofaunal density and species richness were substantially lower in all the cages than in the background (Fig. 3). The most abundant species in the background (Melinna palmata Grube, Apistobranchus tullbergi [Theel] and Paraonidae spp.) were 


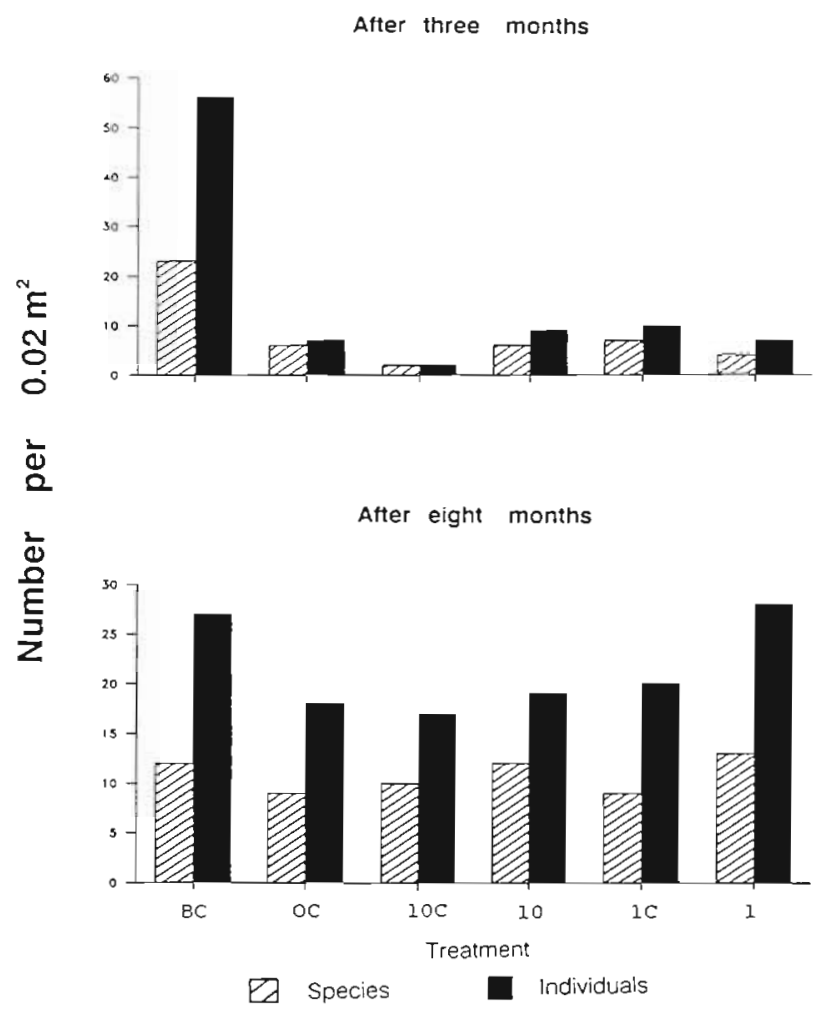

Fig. 3. Macrofauna density and number of species in Ekman grab samples $\left(0.02 \mathrm{~m}^{2}\right)$ in all treatments and the background after 3 and 8 mo. Treatments presented are: $\mathrm{BC}$, background controli $O C$, open control cages; $10 \mathrm{C}, 10 \mathrm{~mm}$ control cages; 10,10 mm cages; 1C, $1 \mathrm{~mm}$ control cages; and 1,1 mm cages

not found in the experimental cages. There were no species in the cages that seemed to be opportunistic and take advantage of the situation.

The picture was considerably different after $8 \mathrm{mo}$. Both the density and the number of species in the cages had significantly increased (Mann-Whitney U test, $\mathrm{p}<$ 0.05 ) and were similar to those of the background (Fig. 3). However, Melinna palmata was still the dominant species in the background and was not recorded inside the experimental cages. The most abundant species in the cages were Terebellides stroemii Sars, Scalibregma inflatum Rathke, Nephtys spp. and Lumbrineridae sp., although none were clearly dominant.

Much less activity was visually evident inside the $1 \mathrm{~mm}$ cages after 3 mo than in the rest of the cages, when photographs were compared. The surface structure of the sediment inside the $1 \mathrm{~mm}$ cages was smooth, without signs of macrofaunal activity. In all other cages epibenthic fauna had clearly invaded and produced various traces.

\section{Meiofauna}

Nematodes and copepods were common in all samples, while polychaetes were important in some. Cer- tain groups occurred with high frequency but in low numbers e.g. priapulid larvae, kinorhynchs, and halacarids, whereas others were infrequent such as amphipods, ostracods, oligochaetes and the chaetognath Spadella sp.

\section{Nematodes}

After 1 mo of recolonization (Fig. 4) there was a significant difference between treatments $(p<0.001)$. nematodes being in the background areas in much higher densities than in the cages. The number of nematodes remained very similar in all treatments after

\section{Nematodes}
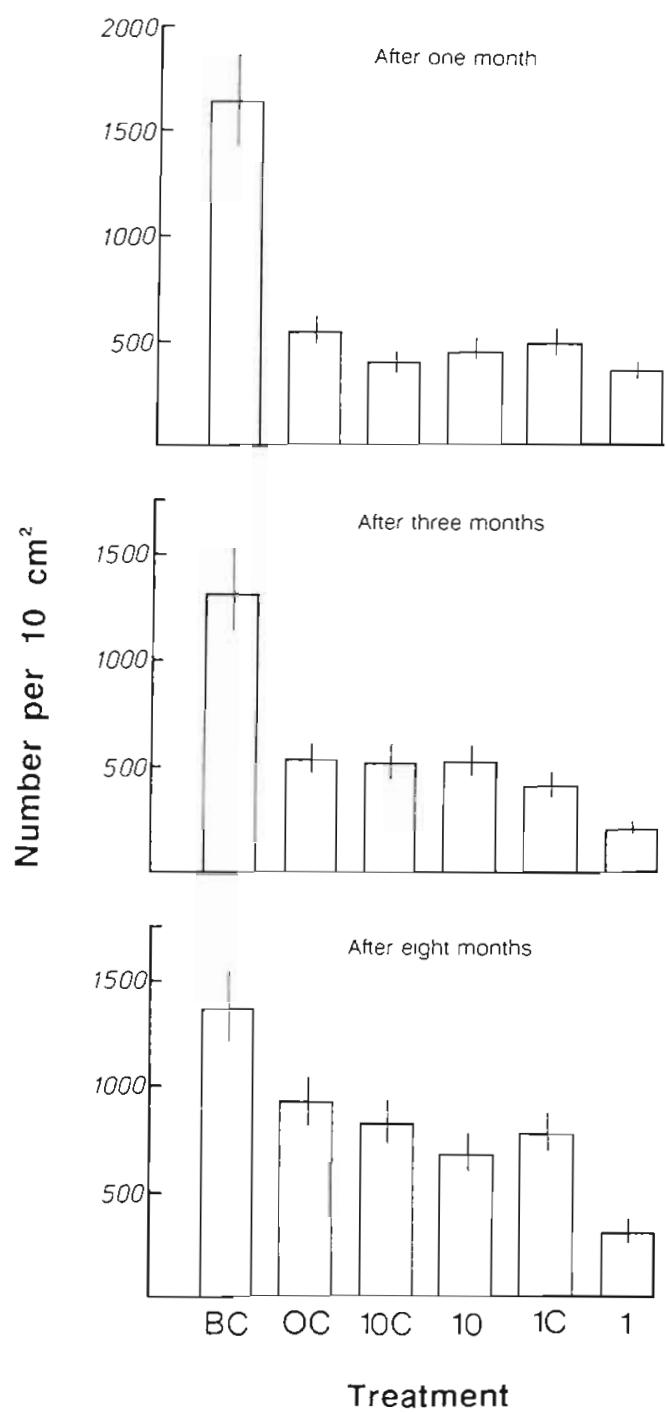

Fig. 4. Average number per $10 \mathrm{~cm}^{2}$ ( $\pm 1 \mathrm{SE}$ ) of nematodes in all. treatments and the background after 1,3 and 8 mo of recolonization (BC: background control; $O C$ : open control cages; 10C: $10 \mathrm{~mm}$ control cages; $10: 10 \mathrm{~mm}$ cages; $1 \mathrm{C}: 1 \mathrm{~mm}$ control cages; $11 \mathrm{~mm}$ cages) 
3 mo. After 8 mo nematode density increased from the third month in all the cages (Mann-Whitney $U$ test, $p<$ 0.01). However, after 8 mo nematodes were still in lower densities in all the cages than in the background (Fig. 4), being significant at $p=0.063$.

\section{Copepods (adults and copepodites)}

Although the copepods were after 1 mo of colonization on average in lower numbers in the experimental cages than in the background, they were clearly more successful in colonizing the azoic sediments than the nematodes (Fig.5). As the residual variance after 1 mo was not homogeneous, a nonparametric test was employed and

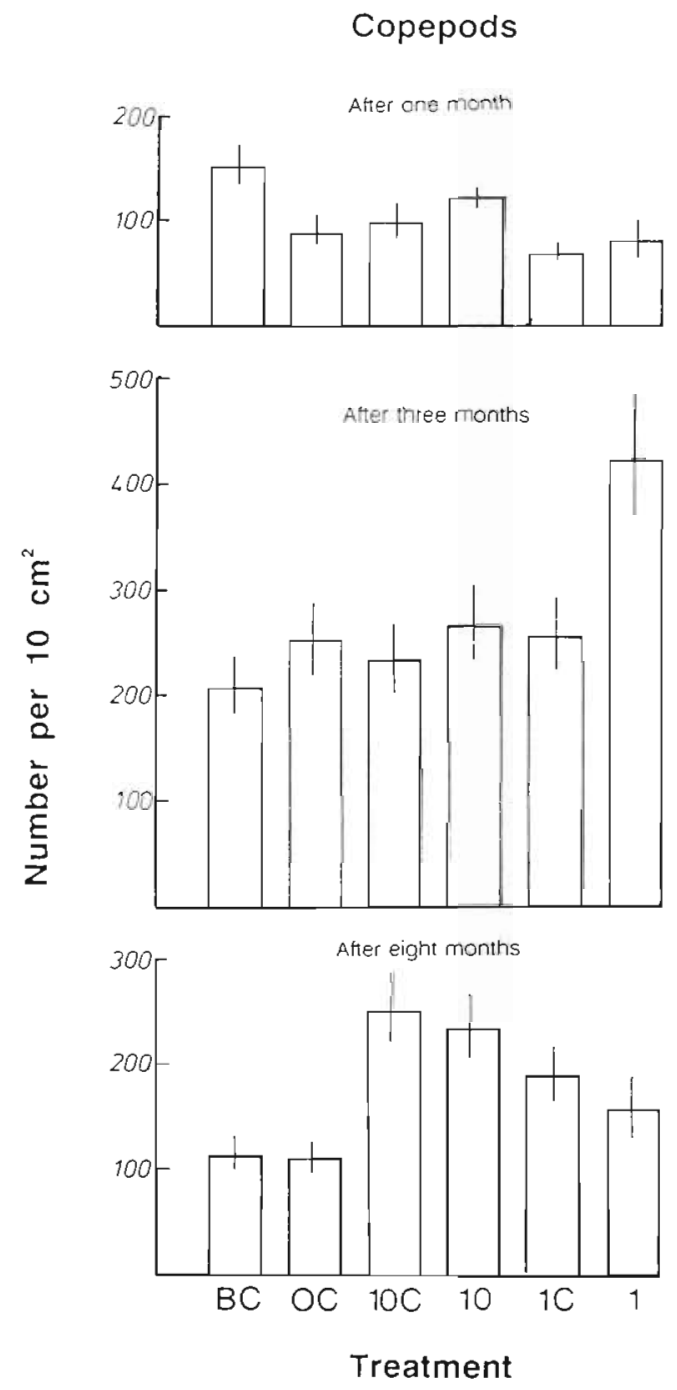

Fig. 5. Average number per $10 \mathrm{~cm}^{2}$ ( $\pm 1 \mathrm{SE}$ ) of copepods in all treatments and the background after 1,3 and 8 mo of recolonization (BC: background control; OC: open control cages; $10 \mathrm{C}$ : $10 \mathrm{~mm}$ control cages; 10: $10 \mathrm{~mm}$ cages; $1 \mathrm{C}: 1 \mathrm{~mm}$ control cages; $1: 1 \mathrm{~mm}$ cages) resulted in a significant difference (Kruskal Wallis 1-way analysis by ranks, $p<0.01$ ). There was an increase in copepod densities after 3 mo in all treatments and the background (Fig. 5), and in all treatments the densities had at least reached the background level. In the $1 \mathrm{~mm}$ cages, copepods were in much higher abundance than in the rest of the treatments (Fig. 5), this being significant at $p=0.069$. After 8 mo there was a significant difference between the treatments ( $p<0.05$ ), background and open control being on average in lower numbers than the rest of the treatments. There was a significant difference $(\mathrm{p}<$ 0.05 ) between sampling dates for all treatments apart from the background control.

\section{Nauplii}

No significant difference was detected in the abundance of nauplii after $1 \mathrm{mo}$ (Fig. 6). After 3 mo there was a significant difference $(p<0.01)$ between treat-
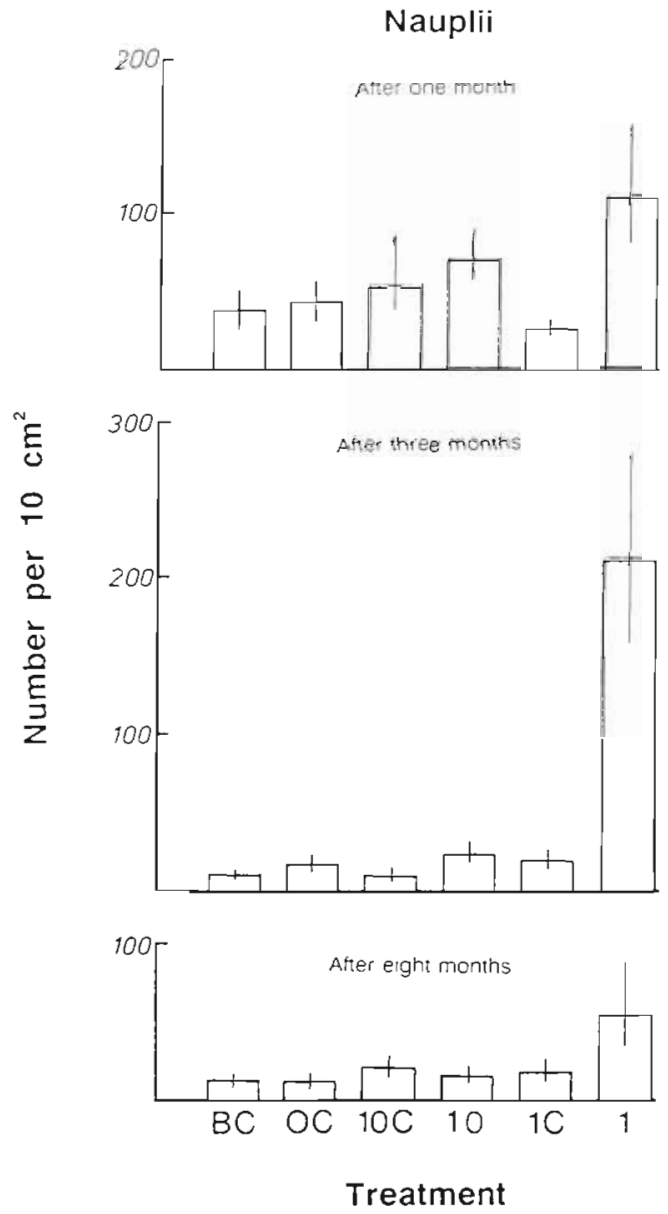

Fig. 6. Average number per $10 \mathrm{~cm}^{2}$ ( $\pm 1 \mathrm{SE}$ ) of nauplii in all treatments and the background after 1,3 and $8 \mathrm{mo}$ of recolonization (BC: background control; OC: open control cages; $10 \mathrm{C}$ : $10 \mathrm{~mm}$ control cages; $10: 10 \mathrm{~mm}$ cages; $1 \mathrm{C}: 1 \mathrm{~mm}$ control cages; $1: 1 \mathrm{~mm}$ cages) 
ments, the density of nauplii being by far the highest inside the $1 \mathrm{~mm}$ cages (Fig. 6), where adult copepods and copepodites were also in highest numbers. There was no significant difference between treatments after $8 \mathrm{mo}(\mathrm{p}>0.05)$.

\section{Polychaetes}

Densities of polychaetes were after 1 mo about 3 times lower in the cages than in the background (Fig. 7 , Mann-Whitney U test, $\mathrm{p}<0.01$ ). However after 3 mo they reached the ambient level in all the cages. After 8 mo the total number of polychaetes inside the $1 \mathrm{~mm}$ cages were in much higher numbers (Fig. 7) than in the rest of the cages and significantly higher inside the exclosure cages than in the rest of the treatments (Mann-Whitney U test, $\mathrm{p}<0.05$ ). The observed differences were mainly due to Ophryotrocha spp.

The extremely high number of polychaetes (mainly Ophryotrocha spp.) in the $1 \mathrm{~mm}$ cages after $8 \mathrm{mo}$ (on average 384 ind per $10 \mathrm{~cm}^{2}$ ) coincided with the reduction of copepods in the same cages.

\section{DISCUSSION}

The ideal way to evaluate the effects of predation/ disturbance on meiofaunal communities is to approach the problem from different angles. In connection with exclusion experiments to estimate overall effects, one can apply enclosures to evaluate effects of specific animals. The results from such studies may then give rise to laboratory experiments, where under controlled conditions different levels of predation/disturbance can be applied on the meiobenthos. In the current study it was found that both enclosure and laboratory experiments were not feasible. This was mainly due to the fact that potential predators were either caught in too low numbers, or when in sufficient numbers the state of the animals was generally too poor to use in an experimental setup.

Reise (1985) reviewed caging methodology and pointed out the problems and how to deal with them (see also Arntz 1977, Virnstein 1977, 1978, Hulberg \& Oliver 1980). By choosing a sheltered site and the use of partial cages as controls, one can reduce and estimate physical artifacts. Still there are some obstacles that are difficult to overcome. Drifting algae may become trapped by the cages (Hulberg \& Oliver 1980, Arntz 1981) and fouling and predator attraction are problems that are not uncommon in caging experiments.

In this exclusion experiment, fouling of the cages was evident after 2 and 3 . mo. This involved mainly ascid-

\section{Polychaetes}
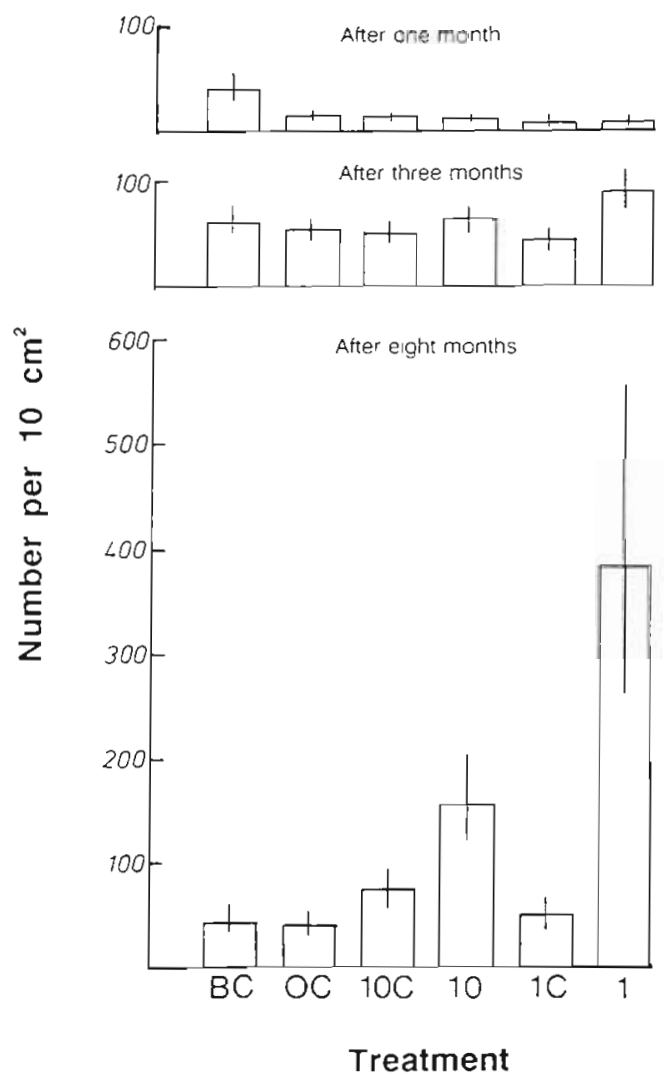

Fig. 7. Average number per $10 \mathrm{~cm}^{2}( \pm 1 \mathrm{SE}$ ) of polychaetes in all treatments and the background after 1,3 and $8 \mathrm{mo}$ of recolonization (BC: background control; $\mathrm{OC}$ : open control cages; 10C: $10 \mathrm{~mm}$ control cages; 10: $10 \mathrm{~mm}$ cages; $1 \mathrm{C}: 1 \mathrm{~mm}$ control cages; 1: $1 \mathrm{~mm}$ cages)

ians, which settled on the cages, both the frame and the netting. The top of the $1 \mathrm{~mm}$ cages also accumulated sediment and detrital matter. However this problem was solved with the partial open cages, which were as much fouled as the others. Congregation of animals inside the cages was not detectable on sampling and inspection dates.

The slow colonization rate of nematodes is in marked contrast with studies performed intertidally where completion of recolonization occurs within hours or days (Sherman \& Coull 1980, Kern \& Taghon 1986, Billheimer \& Coull 1988, Savidge \& Taghon 1988) but in agreement with subtidal studies (Alongi et al. 1983, Sherman et al. 1983, Widboom 1983). Intertidally, where hydrodynamic forces are relatively high, passive resuspension of meiofauna into the water column provides a quick dispersal via currents (see review by Palmer 1988b). At this site currents are minimal so one would expect nematodes to colonize the cages slowly, 
due to their inability to become actively resuspended and take advantage of the relatively quick route of water column transport.

The recolonization of the copepods was much quicker than that of the nematodes and in all the cages their densities reached the background level in 3 mo. In the light of colonization experiments performed subtidally (Alongi et al. 1983, Chandler \& Fleeger 1983, Widboom 1983) and studies on the dispersal mechanism of meiofaunal animals (see review by Palmer 1988b), a comparatively rapid recolonization by the copepods was expected.

Copepods in $10 \mathrm{~mm}, 10 \mathrm{~mm}$ control and $1 \mathrm{~mm}$ control cages reached background densities in 3 mo and maintained that peak to the end of the experiment, although there was a decline both in the background and the open control cages. It is possible that organic enrichment occurred inside these cages $(10,10 \mathrm{C}, 1 \mathrm{C})$ because they all had lids fouled with sessile macrofauna (mainly ascidians), but not the open control cages nor the background. Organic enrichment has been shown to affect the densities of the major meiofaunal taxa (Marcotte \& Coull 1974, Raffaelli \& Mason 1981, Gee et al. 1985, Moore \& Pearson 1986).

It is evident that protection against epibenthic predators in muddy substrata may have profound effects on the meio- and macrobenthos. Inside the $1 \mathrm{~mm}$ cages the number of copepods after 3 mo was much higher than in the rest of the treatments. As the $1 \mathrm{~mm}$ control cages, that should have similar physical conditions to the $1 \mathrm{~mm}$ cages, were not different from the open control, $10 \mathrm{~mm}$ control and $10 \mathrm{~mm}$ cages as far as the number of copepods is concerned, then it is most unlikely that cage artefacts brought this about. It appears that biological factors accounted for elevated numbers of copepods inside the $1 \mathrm{~mm}$ cages after $3 \mathrm{mo}$.

The meiofauna inside the $1 \mathrm{~mm}$ cages was protected from almost all macroepifauna. In the other cages there was, however, free access of these animals, although in the $10 \mathrm{~mm}$ cages only small and medium sized macrofauna were allowed to enter. There was no apparent difference between all the cages as far as macroinfauna was concerned, so it appears that small and medium sized natant epifauna (able to enter $10 \mathrm{~mm}$ cages) was controlling the densities of the copepods, either by predation/disturbance or competition for food. However, it is difficult to pinpoint one particular species that could be regulating the copepod densities at this site, although a few possible candidates can be identified. Based on underwater observations and the results from trawling, the epifauna was mainly composed of shrimps, crabs and small fish. The bulk of the crabs were too large to enter the $10 \mathrm{~mm}$ cages, whereas the fish and the shrimps were able to.
Crangon crangon (L.), the dominant species in the trawl, is known to feed on copepods (Reise 1979, Gee et al. 1985) and harpacticoid copepods have been found to be one of the dominant food items of juveniles (Pihl \& Rosenberg 1984). When gut contents of 20 specimens of various size classes were analyzed there was no sign of meiofauna: most stomachs were empty, a few contained detritus and one contained polychaete remains. However, the brown shrimp eats mainly during the night and the stomach content can drop to a very low level in the afternoon (Pihl \& Rosenberg 1984) which may explain our results as samples were taken at that time.

Gobies are known to prey upon copepods (see Gee 1989 for review, pers. obs. from study site) and their presence at the study site might have had an effect on the copepod numbers as they could enter the $10 \mathrm{~mm}$ cages but not the $1 \mathrm{~mm}$ cages. However, lack of combined pressure (predation, disturbance and competition) exerted on the copepods by a variety of natant macrofaunal species may be the most likely cause of increased density within the $1 \mathrm{~mm}$ cages after $3 \mathrm{mo}$.

The reduction of copepod numbers inside the $1 \mathrm{~mm}$ cages after 8 mo could be attributable to densitydependent factors. One might be tempted to explain this reduction by interspecific competition as there was a simultaneous increase in polychaetes as copepods decreased. On the other hand it is equally possible that intraspecific competition was occurring and this can only be tested with laboratory experiments. The decline could also be explained by natural seasonal reduction, as happened in the background area and the open control cages.

Meiobenthic polychaetes, many of them belonging to the nonpermanent meiofauna, were also clearly protected inside the $1 \mathrm{~mm}$ cages, but not until after $8 \mathrm{mo}$. This slow response to exclusion may be explained by a slower colonization rate compared to copepods. The exclusion of larger epibenthic predators (cages with $\geq$ $10 \mathrm{~mm}$ mesh) often results in higher densities of macroinfauna (Reise 1977, 1978, Virnstein 1977, 1979, Peterson 1979, Holland et al. 1980, Dauer et al. 1982). In contrast to copepods, polychaetes were to some extent also protected inside the $10 \mathrm{~mm}$ cages. These polychaetes were larger than copepods and may therefore be preyed on by larger animals.

Acknowledgements. We are indebted to the following divers who made this experiment possible: Brian Bett, Dave Mills, Bob Collington, Gareth Davies, Chris Smith, Alan Hughes and Keith Watson. Thanks are also due to Tom Pearson of the Dunstaffnage Marine Research Laboratory for providing laboratory facilities and setting up equipment for redox measurements. The first author gratefully acknowledges the receipt of grants from the Foreign and Commonwealth Office and the University of Iceland. 


\section{LITERATURE CITED}

Alheit, J., Scheibel, W. (1982). Benthic harpacticoids as a food source for fish. Mar. Biol. 70: 141-147

Alongi, D. M., Boesch, D. F., Diaz, R. J. (1983). Colonization of meiobenthos in oil-contaminated subtidal sands in the lower Chesapeake Bay. Mar. Biol. 72: 325-335

Arntz, W. E. (1977). Results and problems of an 'unsuccessful benthos cage experiment (Western Baltic). In: Keegan, $\mathrm{P}$ Cerdigh, P., Boaden. P. (eds.) Biology of benthic organisms. Pergamon Press, New York, p. 31-34

Arntz, W. E. (1981). Entwicklung von marinen Bodentiergemeinschaften bei Ausschluß von Räubern: Nur Artefakte? Meeresforschung 28: 189-204

Bell, S. S. (1980). Meiofauna-macrofauna interactions in a high salt marsh habitat. Ecol. Monogr. 50: 487-505

Bell, S. S., Coull, B. C. (1978). Field evidence that shrimp predation regulates meiofauna. Oecologia 35: 141-148

Berge, J. A., Valderhaug, V. A. (1983). Effect of epibenthic macropredators on community structure in subtidal organically enriched sediments in the inner Oslofjord. Mar. Ecol. Prog. Ser 11: 15-22

Billheimer, L. E., Coull, B. C. (1988). Recolonization of meiobenthos into juvenile spot (Pisces) feeding pits. Estuar. coast. Shelf Sci. 27: 335-340

Buzas, M. A. (1978). Foraminifera as prey for berithic deposit feeders: results of predator exclusion experiments. J. mar. Res. 36: 617-625

Chandler, G. T., Fleeger, J. W. (1983). Meiofaunal colonization of azoic estuarine sediment in Louisiana: Mechanisms of dispersal. J. exp. mar. Biol. Ecol. 69 (2): 189-202

Coull, B. C., Bell, S. S. (1979). Perspectives of marine meiofaunal ecology. In: Livingson, R. J. (ed.) Ecological Proces ses in Coastal and Marine Systems. Plenum Press, New York, p. 189-216

Coull, B. C., Bell, S. S., Savory, A. M., Dudley, B. W (1979) Zonation of meiobenthic copepods in a southeastern United States salt marsh. Estuar coast. mar. Sci. 9: $181-188$

Dauer, D. M., Ewing, R. M., Tourtellotte, G. H., Harlan, W T. Sourbeer, J. W., Barker, H. R. (1982). Predation, resource limitation and the structure of benthic infaunal communities of the lower Chesapeake Bay. Int. Revue ges. Hydrobiol. $67: 477-489$

Fitzhugh, G. R., Fleeger, J. W. (1985). Goby (Pisces: Gobiidae) interactions with meiofauna and small macrofauna. Bull mar. Sci. 36: 436-444

Gage, J. (1972a). A preliminary survey of the benthic macrofauna and sediments in Lochs Etive and Creran, sealochs along the west coast of Scotland. J. mar. biol. Ass U.K. 52: $237-276$

Gage, J. (1972b). Communaty structure of the benthos in Scottish sea-lochs. I. Introduction and species diversity Mar. Biol. 14: 281-297

Gee, J. M. (1987). Impact of epibenthic predation on estuarine intertidal harpacticoid copepod populations. Mar Biol. 96 $497-510$

Gee, J.M. (1.989). An ecological and economic review of meiofauna as food for fish. Zool. J. Linn. Soc. 96: 243-261

Gee, J. M., Warwick, R. M., Davey, J. T , George, C. L. (1985). Field experiments on the role of epibenthic predators in determining prey densities in an estuarme mudflat. Estuar. coast. Shell. Sci. $21 \quad 429-488$

Harris, R. P. (1972). The distribution and ecology of the interstitial meiofauna of a sandy beach at Whitsand Bay East Cornwall. J. mar biol. Ass. U.K. 52: 1-18

Hicks, G. F. R. (1984). Spatio-temporal dynamics of a meiobenthic copepod and the impact of predation-disturbance. J. exp. mar. Biol. Ecol. 81: 47-72

Hicks, G. R. F., Coull, B. C. (1983). The ecology of marine meiobenthic harpacticoid copepods. Oceanogr mar. Biol. A. Rev. $2167-175$

Hockin, D. C. (1982). Further records of meiofauna predation and implications for the community stability. Crustaceana 42 (1): 106-107

Hoffman, J. A., Katz, J., Bertness, M. D. (1984). Fiddler crab deposit feeding and meiofaunal abundance in salt marsh habitats. J. exp. mar. Biol. Ecol. 82: 161-174

Holland, A. F., Mountford, N. K., Hiegel, M. H., Kaumeyer, K. R., Mihursky (1980). Influence of predation on infaunal abundance in upper Chesapeake Bay, USA. Mar. Biol 57 . $221-235$

Hulberg, L. W., Oliver, J. S. (1980). Caging manipulations in marine soft-bottom communities: importance of animal interactions or sedimentary habitat modifications. Can. J. Fish. aquat. Sci. 37: 1130-1139

Hurlbert, S.H. (1984). Pseudoreplication and the design of ecological field experiments. Ecol. Monogr. 54: 187-211

Jansson, B.-O. (1968). Quantitative and experimental studies of the interstitial fauna in four Swedish sandy beaches Ophelia 5: 1-71

Kern, J. C., Taghon, G. L. (1986). Can passive recruitment explain harpacticoid copepod distributions in relations to epibenthic structures? J. exp. mar. Biol. Ecol. 101: 1-23

Marcotte, B. M. Coull, B. C. (1974). Pollution, diversity and meiobenthic communities in the north Adriatic (Bay of Pyran, Yugoslavia). Vie Milieu 24: 281-300

McIntyre, A. D. (1956). The use of trawl, grab and camera in estimating marine benthos. J. mar. biol. Ass. U. K. 35 $419-430$

McIntyre, A. D., Murison, D. J. (1973). The meiofauna of a flatfish nursery ground. J. mar. biol. Ass. U.K. 53: 93-118

Mielke, W. (1976). Okologie der Copepoda eines Sandstrandes der Nordseeinsel Sylt. Mikrofauna Meeresbod. 59: 1-86

Moore, C. G. (1979). The zonation of psammolittoral harpacticoid copepods around the Isle of Man. J. mar. biol. Ass. U.K. 59: 711-724

Moore, C. G., Pearson, T. H. (1986), Response of a marine benthic copepod assemblage to organic enrichment. Syllogeus-Natn. Mus. nat. Sci. 58: (Proc. 2nd Int. Conf. Copepoda, Ottawa) p. 369-373

Nichols, J. A., Robertson, R. J. (1979). Field evidence that the eastern mud snail, Ilyanossa absoleta, influences nematode community structure. Nautilus 93: 44-46

Palmer, M. A. (1988a). Epibenthic predators and marine meiotauna: separating predation, disturbance, and hydrodynamic effects. Ecology 69: 1251-1259

Palmer, M. A. (1988b). Dispersal of marine meiofauna: a review and conceptual model explaining passive transport and active emergence with implications for recruitment. Mar. Ecol. Prog. Ser. 48: 81-91

Pearson, T. H., Stanley, S. O. (1979). Comparative measurement of the redox potential of marine sediments as a rapid means of assessing the effect of organic pollution. Mar Biol. 53: 371-379

Peterson, C. H. (1979) Predation, competitive exclusion and diversity in the soft benthic communities of estuaries and lagoons. In: Livingson, R. J. (ed.) Ecological processes in coastal and marine systems. Plenum Press, New York, p. $233-264$

Pihl, L., Rosenberg, R. (1984). Food selection and consumption of the shrimp Crangon crangon in some shallow marine areas in western Sweden. Mar. Ecol. Prog. Ser. 15: 159-168

Platt, H. M., Warwick, R. M. (1983). Free-living marine 
nematodes. Part I. British Enoplids. In: Kermach, D. M., Barnes, R. S. K. (eds.) Synopses of the British Fauna (New Series), 38. Cambridge University Press, Cambridge, p. $1-307$

Raffaelli, D., Mason, C. F. (1981). Pollution monitoring with meiofauna, using the ratio nematodes to copepods. Mar Pollut. Bull. 12: 158-163

Raffaelli, D. G., Milne, H. (1987). An experimental investigation of the effects of shorebird and flatfish predation on estuarine invertibrates. Estuar coast. Shelf Sci. 24: 1-13

Reise, K. (1977). Predator exclusion experiments in an intertidal mudflat. Helgoländer wiss. Meeresunters. 30: 263-271

Reise, K. (1978). Experiments on epibenthic predation in the Wadden Sea. Helgoländer wiss. Meeresunters. 31. 55-101

Reise, K. (1979). Moderate predation on meiofauna by the macrobenthos of the Wadden Sea. Helgoländer wiss. Meeresunters. 32: 453-465

Reise, K. (1985). Tidal flat ecology. Springer, Berlin

Robertson, J. R., Newell, S. Y (1982). A study of particle ingestion by three fiddler crab species foraging in sandy sediments. J. exp. mar. Biol. Ecol. 65: 11-17

Savidge, W. B., Taghon, G. L. (1988). Passive and active components of colonization following two types of disturbance on intertidal sandflat. J. exp. mar. Biol. Ecol. 115: 137-155

Scherer, B., Reise, K. (1981). Significant predation on microand macrobenthos by the crab Caricinus maenas $\mathrm{L}$. in the Wadden Sea. Kieler Meeresforsch. Sonderh. 5: 490-500

Sherman, K. M., Coull, B. C. (1980). The response of meiofauna to sediment disturbance. J. exp. mar. Biol. Ecol. 46: $59-71$

This article was presented by Dr R. M. Warwick, Plymouth, United Kingdom
Sherman, K. M., Reidenauer, J. A., Thistle, D., Meeter, D. (1983). Role of natural disturbance in an assemblage of marine free-living nematodes. Mar Ecol. Prog. Ser 11 23-30

Smith, L. D., Coull, B. C. (1987). Juvenile spot (Pisces) and grass shrimp predation on meiobenthos in muddy and sandy substrata. J. exp. mar Biol. Ecol. 105: 123-136

Sogard, S. M. (1984). Utilization of meiofauna as a food source by a grassbed fish. the spotted dragonet Callionymus pauciradiatus. Mar Ecol. Prog. Ser. 17. 183-191

Teal, J. M. (1962). Energy flow in the salt marsh ecosystem of Georgia. Ecology 43: 614-624

Underwood, A. J. (1982). Techniques of analysis of variance in experimental marine biology and ecology. Oceanogr. mar. Biol. A. Rev. 19: 513--605

Virnstein, R. W. (1977). The importance of predation by crabs and fishes on benthic infauna in Chesapeake Bay. Ecology 58: $1199-1217$

Virnstein, R. W. (1978). Predator caging experiments in soft sediments: caution advised. In: M. I. Wiley (ed.) Estuarine interactions. Academic Press, New York, p. 261-263

Virnstein, R. W. (1979). Predation on estuarine infauna: response of component species. Estuaries 2: 69-86

Warwick, R. M., Davey, J. T., Gee, J. M., George, C. L. (1982). Faunistic control of Enteromorpha blooms: a field experiment. J. exp. rnar. Biol. Ecol. 56: 23-31

Widbom, B. (1983). Colonization of azoic sediment by sublittoral meiofauna in Gullmar Fjord-Swedish West coast. Oceanologica Acta. vol. spec. (Proc. 17th Europ. Mar. Biol Sympos.): $213-217$

Manuscript first received: September 11, 1989

Revised version accepted May 25, 1990 